УДК 621.396.677

DOI: https://doi.org/10.26642/ten-2021-2(88)-103-112

Н.М. Каращук, к.т.н., доц. Житомирський військовий інститут імені С.П. Корольова

В.П. Манойлов, д.т.н., проф.

П.П. Мартинчук, ст. викладач

В.В. Чухов, к.т.н., доц.

Державний університет «Житомирська політехніка»

\title{
Вимірювання добротності НВЧ-резонаторів за допомогою мостового методу
}

Для вимірювання параметрів НВЧ-резонаторів зазвичай застосовуються різноманітні методи, у яких використовують різні хвилеводні елементи, такі як спрямовані відгалужувачі або різні гібридні з'єднання. У роботі розглядаються основні схеми вмикання об'ємних металевих резонаторів у лінї передачі та їхні параметри.

Використовувані методи вимірювання параметрів резонаторів мають велику трудомісткість настроювання та низьку точність. Мостові методи із використанням Т-трійника мають крашу точність вимірювань, проте їхнім недоліком є використання підстроювальних елементів у вигляді иттрів чи діафрагм для балансування мостової схеми, що призводить до збільшення тривалості вимірювання.

У роботі розглянуто метод вимірювання параметрів добротності НВЧ-резонаторів 3 використанням неузгодженого T-мосту, який не має наведених вище недоліків.

Описано методику вимірювань та запропоновано автоматичну установку із застосуванням ПЕОМ. За експериментальними даними способом графічної побудови на круговій діаграмі можна визначити всі основні параметри резонаторів. Також наведено формули для оцінки похибки вимірювання параметрів резонаторів.

Ключові слова: добротність; НВЧ-резонатор; мостовий метод вимірювання.

Актуальність теми. У техніці надвисоких частот (НВЧ) широко застосовуються хвилеводні лінії передачі, які можуть зокрема під'єднуватися до різного типу коливальних систем. Серед інших доцільними в такому випадку є об’ємні НВЧ-резонатори, які мають переваги за смугою пропускання та добротністю. Для використання об'ємних НВЧ-резонаторів має місце необхідність постійно розвивати методи розрахунку та методи вимірювання їх параметрів, зокрема добротності.

Аналіз останніх досліджень та публікацій, на які спираються автори. Для вимірювання параметрів НВЧ-резонаторів, як правило, використовують спрямовані відгалужувачі чи різні гібридні 3’єднання [1-5].

Так у [6] для вимірювання добротності було використано закономірності зміни вхідного опору резонатора в околі резонансної частоти, а також частотна залежність його коефіцієнта передачі. Дослідження цих закономірностей показує три можливі шляхи вимірювання добротностей (рис. 1).

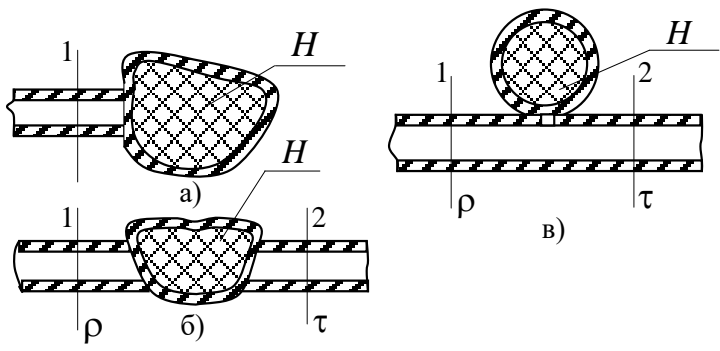

Рис. 1. Типові схеми вмикання об'ємних резонаторів ( $а$-кінцевий елемент; б - прохідний; в -як неоднорідність у лінії)

У першому випадку (рис. 1, a) досліджуваний резонатор є кінцевим навантаженням. У другому випадку (рис. 1, б) він працює як прохідний елемент. Якщо резонатор вмикається, як на рисунку 1,6 , де він $\epsilon$ неоднорідністю, яка визначає частотну залежність рівня прохідних та відбитих хвиль у лінії.

Основними параметрами резонаторів у системі є власна добротність $Q_{0}$, навантажена добротність $Q_{H}$ і зовнішня добротність $Q_{\xi}$, а також довжина хвилі. 
Резонатори застосовують не ізольовано, а у поєднанні із навантаженнями. За цього електромагнітна енергія може розсіюватися не тільки у самій коливальній системі резонатора, але і на навантаженнях. Повна енергія розсіюється за період високочастотного коливання за формулою

$$
W_{\text {розс.пов }}=W_{\text {розс.рез. }}+W_{\text {розс.нав }} .
$$

Добротність резонатора з урахуванням усіх приєднаних навантажень називається навантаженою добротністю $Q_{H}$. Величину $Q_{H}$ обчислюють:

$$
Q_{н}=\frac{\omega_{0} W_{\text {нав }}}{P_{\text {розс.пов }}},
$$

де $W_{\text {нав }}$ - енергія, накопичена в самому резонаторі;

$P_{\text {розс.пов }}$ - сумарна потужність розсіювання у резонаторі і в навантаженні;

$\omega_{0}$ - резонансна кутова частота.

Вираз (2) можна записати так

$$
Q_{H}=\frac{\omega_{0} W_{\text {нав }}}{P_{\text {розс.рез }}+P_{\text {розс.нав. }}},
$$

або

$$
\frac{1}{Q_{н}}=\frac{P_{\text {розс.рез }}}{\omega_{0} W_{\text {нав }}}+\frac{P_{\text {розс.нав }}}{\omega_{0} W_{\text {нав }}} .
$$

Перший доданок у правій частині виразу (4) відповідає навантаженій добротності $Q_{H}$; другий доданок також має характер величини, оберненої деякій частині навантаженої добротності $Q_{H} 3$ урахуванням потужності розсіювання в навантаженні. Тому вводиться поняття зовнішньої добротності $Q_{3}$, яка визначається виразом (5)

$$
Q_{3}=\frac{\omega_{0} W_{\text {нав }}}{P_{\text {розс.нав }}}
$$

Отже, зовнішня добротність визначається як відношення енергії, нагромадженої у самому резонаторі, до енергії, розсіяної у навантаженні за період високочастотного коливання.

Вираз (5) можна записати так:

$$
\frac{1}{Q_{н}}=\frac{1}{Q_{0}}+\frac{1}{Q_{3}} .
$$

Якщо резонатор має тільки один елемент зв'язку (один вхід), то під час вимірювання параметрів його під'єднують до лінії як двополюсник [7]. Резонатор з двома елементами зв'язку (один для зв'язку 3 генератором, інший для зв'язку з навантаженням) під’єднують як чотириполюсник, тобто вмикають «на прохід».

Найбільш трудомісткою операцією під час вимірювання добротності $є$ вимірювання частоти $\mathrm{i}$ розстроювання.

У діапазоні низьких частот достатньо поширеним методом вимірювання параметрів електричних кіл є мостовий метод. У діапазоні НВЧ також застосовуються схеми, аналогічні мостовим.

Суть вимірювання в обох випадках однакова - порівняння вимірюваного параметра, наприклад, опору, зі зразковим. На низьких частотах як зразкові міри, так само і мостові схеми реалізуються легко.

Зі збільшенням частоти створення зразкових мір мостових схем поступово ускладнюється. У діапазоні НВЧ можна використовувати такі конструкції, що працюють подібно до мостів, - подвійні трійники, кільцеві мости, спрямовані відгалужувачі тощо.

Для зрівноваження моста потрібні два незалежні регулювання, за допомогою яких можна було б балансувати модулі та фази досліджуваного й зразкового навантажень. У використовуваних мостових схемах ці два регулювання звичайно незалежні.

Значення вимірюваного повного опору можна визначати безпосередньо за допомогою каліброваного зразкового опору. Точність вимірювання залежить від точності калібрування зразкового повного опору. Конструкції двох мостів, які широко використовують у діапазоні НВЧ, показано на рисунку 2. Особливості цих конструкцій описано в [8]. 


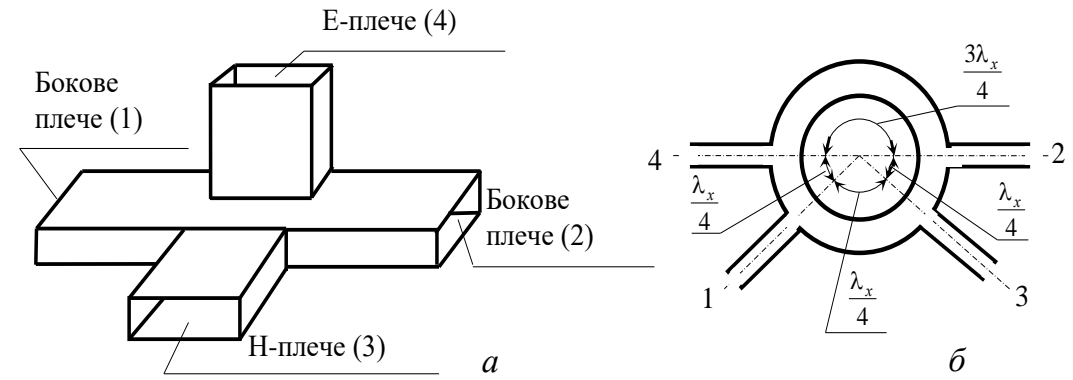

Рис. 2. Конструкції мостів НВЧ

Метою статті є розгляд методу дослідження резонаторів, який відрізняється простотою і точністю через повніше використання властивостей несиметричного подвійного хвилеводного трійника.

Вмикання короткозамикаючого поршня і атенюатора у протилежне відносно до вимірюваного об’єкта плече моста дозволяє усунути недоліки використання узгодженого мосту.

Викладення основного матеріалу. Розглянемо можливість застосування подвійного хвилеводного трійника (рис. 2,a) для вимірювання повного опору за умови, що конструкція хвилеводного трійника симетрична і всі його плечі узгоджено.

На підставі принципу взаємності в теорії багатополюсників доводиться, що коли до одного з бокових плечей під'єднати джерело коливань, то енергія розподіляється порівну між Е- і Н-плечами подвійного трійника і не надходить у друге бокове плече. Ці властивості справедливі лише при ідеальній симетрії конструкції та узгоджених плечах.

Принцип дії кільцевого моста (рис. 2, б) коаксіального типу грунтується на тому, що хвилі, які поширюється за і проти ходу годинникової стрілки, на вході плечей зсунуті за фазою так, що забезпечується нормальна робота моста.

Наприклад, коли до плеча 4 під’єднати джерело коливань, то у плече 3 енергія не підходить, бо різниця зсуву фаз для хвиль, які поширюються за і проти ходу годинникової стрілки, дорівнює $\pi$. Кільцеві мости є більш вузькосмуговими пристроями, ніж подвійні трійники, тому вони менш поширені у вимірювальній техніці.

Розглянемо мостову схему вимірювання повного опору, що має подвійний хвилевідний трійник. Якщо генератор сигналів приєднано до Н-плеча (рис. 3), детекторна секція до Е-плеча, а зразковий опір до одного з бокових плечей, то міст буде зрівноважено, тобто струм на виході детектора дорівнюватиме нулю лише тоді, коли до другого бокового плеча приєднано опір, який дорівнює зразковому.

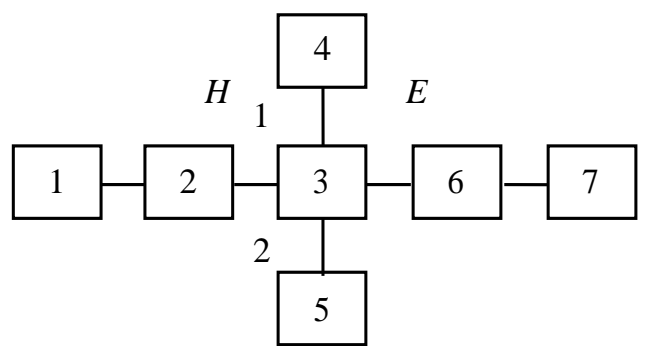

Рис. 3. Структурна схема для вимірювання повного опору за допомогою хвилеводного моста (1-генератор НВЧ; 2 - змінний атенюатор; 3 -хвилевідний трійник;

4, 5 - зразковий та вимірювальний опори; 6-детектор; 7 -індикатор)

За цього напруженість електричного поля хвиль, відбитих від зразкового і вимірюваного опорів, в Е-плечі будуть рівні і протифазні. Отже, коли рівні модулі і фази коефіцієнтів відбиття від зразкового і вимірюваного опорів, покази індикатора на виході детекторної секції дорівнюватимуть нулю.

Змінний зразковий повний опір у діапазоні НВЧ реалізувати складно. Тому описаний міст використовують лише тоді, коли достатньо встановити тільки наявність відхилення виміряного повного опору від зразкового.

В описаному методі потрібно використовувати два ідентичні детектори і узгоджені навантаження, якість виготовлення яких накладає істотні обмеження на точність вимірювання.

Недоліком мостових вимірювачів $є$ вузький частотний діапазон, в якому міст лишається зрівноваженим. 
Практично необхідно зрівноважувати міст на кожній частоті, досягаючи відсутності сигналу у плечі 3 за однакових навантажень, підключених до плечей 1 і 2. Для цього мости мають елементи регулювання у вигляді неоднорідностей - штирів, діафрагм тощо. Інколи для налаштування використовують узгоджувальні трансформатори, що вмикають між виходами плечей 1 і 2 та навантаженням.

Можна виключити тривалу процедуру врівноваження мосту для вимірювання повних опорів [9-11].

До плеча 2 (рис. 4, a) підключається зразкове навантаження 7, до плеча 1 - спеціальне навантаження 6 зі змінним за модулем і фазою коефіцієнтом відбиття (генератор 5 підключається до плеча 4). За допомогою пристроїв зрівноваження цього навантаження досягають нульових показів індикатора 8. За додавання хвиль, що входять у плече 3 внаслідок асиметрії моста, відбита хвиля в самому мості і від його фланців, відбита хвиля від зразкового і регульованого навантажень дорівнює нулю. Якщо до плеча 2 замість зразкового підключити вимірюване навантаження 9 (рис. 4, б), то рівність нулю показів індикатора буде вказувати на рівність повних опорів вимірюваного і зразкового навантажень незалежно від ступеня несиметрії моста.

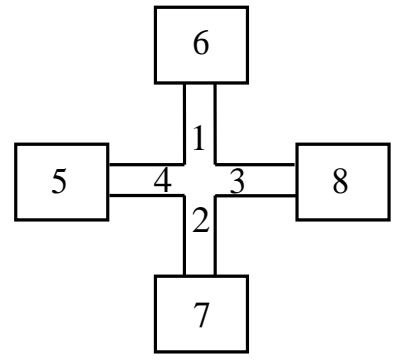

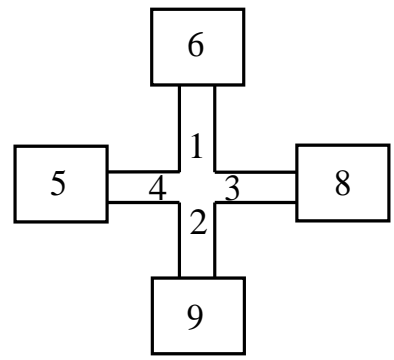

$\sigma$

Рис. 4. Функціональні схеми мостів НВЧ для порівняння повних опорів

Структурну схему автоматичної установки для вимірювання добротності резонатора показано на рисунку 5.

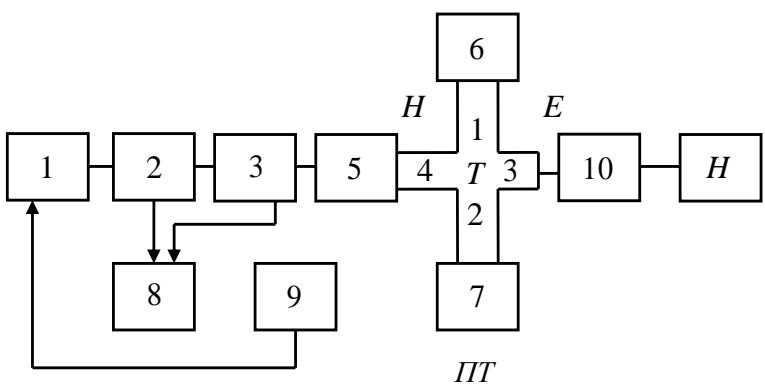

Рис. 5. Структурна схема для вимірювання повного опору за допомогою хвилеводного моста ( 1 - генератор НВЧ, 2, 3 - направлені відгалужувачі, ПТ - подвійний хвилевідний трійник із плечами $3,4 i$ 1, 2, 5 і 7 -атенюатори, 8-блок оброблення, 9-ПЕОМ, 10 - резонатор, H-навантаження)

Для вимірювання добротності резонатора за максимальної смуги зміни частоти генератора вимірюють коефіцієнт стоячої хвилі (КСХ) резонатора, навантаженого на узгоджене навантаження. На основі цих значень КСХ та частот розраховується $Q_{0}$.

Описану методику вимірювання було повністю автоматизовано завдяки сучасним панорамним вимірювачам коефіцієнта стоячої хвилі за напругою (КСХН) (рис. 5).

Принцип дії установки для вимірювання КСХ різних НВЧ-елементів описано у роботах $[9,11]$.

У такому приладі продетектовані сигнали із спрямованих детекторів падаючої та відбитої хвиль панорамного індикатора надходять на блок оброблення, у якому вони підсилюються та перетворюються у цифровий код. Основу генератора коливної частоти такого приладу найчастіше становить генератор синтезованої частоти, керований його мікропроцесором. Функції відображення, керування генератором коливної частоти та оброблення виконує ПЕОМ, що збільшує гнучкість використання такого приладу.

Програмне забезпечення такого приладу дозволяє отримувати залежності вимірюваних параметрів від частоти або потужності, фільтрувати їх, здійснювати статистичне оброблення із різними програмно встановленими параметрами. 
За одержаними результатами можна обчислити власну добротність резонатора $Q_{0}$ за допомогою таких формул [11], коли $К Б X_{\text {макс }}<0,2$ :

$$
Q_{0}=\frac{f_{0}}{\Delta f} \frac{1}{K Б X_{\text {макс }}},
$$

якщо $К Б X_{\text {макс }}>0,2$ :

$$
Q_{0}=\frac{f_{0}}{\Delta f} \frac{1}{K Б X_{\text {макс }}} \sqrt{1-\frac{1}{2} K Б X_{\text {макс }}^{2}},
$$

де $\Delta f$ - зміна коефіцієнта біжучої хвилі (КБХ) на рівні $0,5-0,5 \cdot K Б X_{\text {макс }}$.

Для визначення усіх добротностей $Q_{0}, Q_{H}$, та $Q_{3}$ за результатами вимірювання КБХ залежно від частоти можна скористатися круговою діаграмою нових опорів.

Спочатку за допомогою вимірювальної лінії визначається нормована до хвилевого опору підвідної лінії передачі активна складова вхідного опору резонатора $R / Z_{0}$ на резонансній частоті $f_{0}$. Для цього знаходиться положення вузла на вимірювальній лінії, коли досліджуваний резонатор розстроєний (досягають цього, змінюючи частоту генератора або перестроюючи резонатор), вважаючи наближено, що лінія навантажена на реактивний опір. Встановивши зонд вимірювальної лінії у вузли напруженості електричного поля, налаштовують резонатор до одержання максимального показу індикатора вимірювальної лінії. Це еквівалентно настроюванню резонатора в резонанс із частотою генератора, що відповідає чисто активному опору у місці розташування зонду. Слід зауважити, що активна складова вхідного опору резонатора може бути більша від хвильового опору лінії $\left(R / Z_{0}>1\right)$, або менша $\left(R / Z_{0}<\right.$ 1).

Після настроювання резонатора в резонанс, шляхом переміщення зонду вимірювальної лінії, визначається розподіл поля й вимірюється КСХ мін.

Якщо під час аналізу характеру стоячої хвилі з'ясується, що в місці положення вузла при настроюванні розміщується мінімум напруженості поля, то $\left(R / Z_{0}<1\right)$, а коли максимум, то $\left(R / Z_{0}>1\right)$.

За даними вимірювання можна знайти точку $A$ на осі чисто активних значень $R / Z_{0}$, що відповідає виміряному значенню КБХ макс (рис. 6) або КСХ мін (рис. 7).

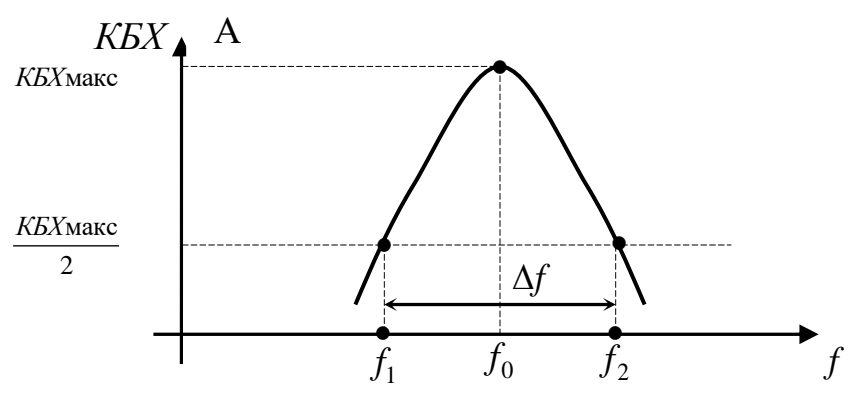

Рис. 6. До визначення добротності резонатора $Q_{0}$

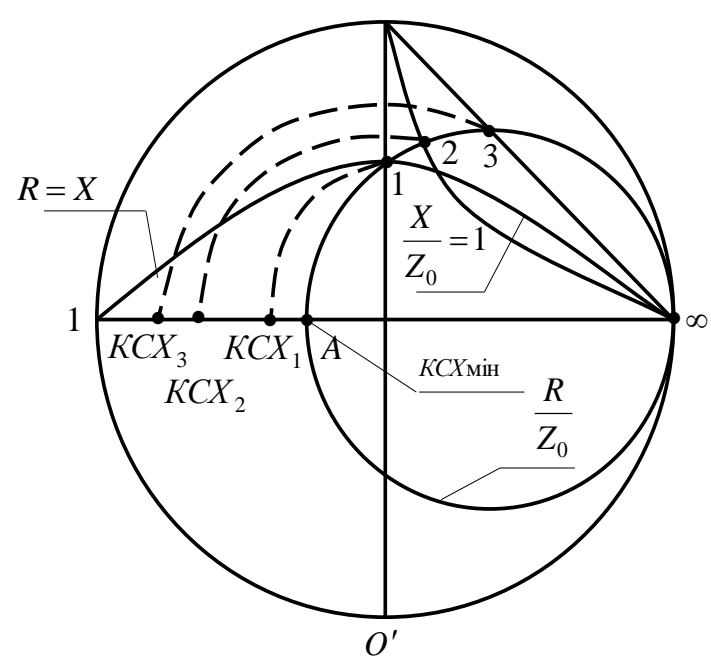

Рис. 7. До визначення параметрів резонатора графічним способом 
Через точку А проходить коло сталого значення $R / Z_{0}$ (рис. 7). Потім визначається залежність КСХ від частоти (рис. 8) і на діаграмі повних опорів (рис. 7) будують допоміжні лінії:

1) геометричне місце точок (рис. 7), якому відповідає $R=X$ (ця крива є дугою кола, що проходить через крайні точки 0 i $\infty$ дійсної осі, із центром, розміщеним на периферії кругової діаграми в точці $O^{\prime}$;

2) дугу кола, яка відповідає $X / Z_{0}=1$;

3) пряму, що сполучає точки $R / Z_{0}=\infty \mathrm{i} X / Z_{0}=1$.

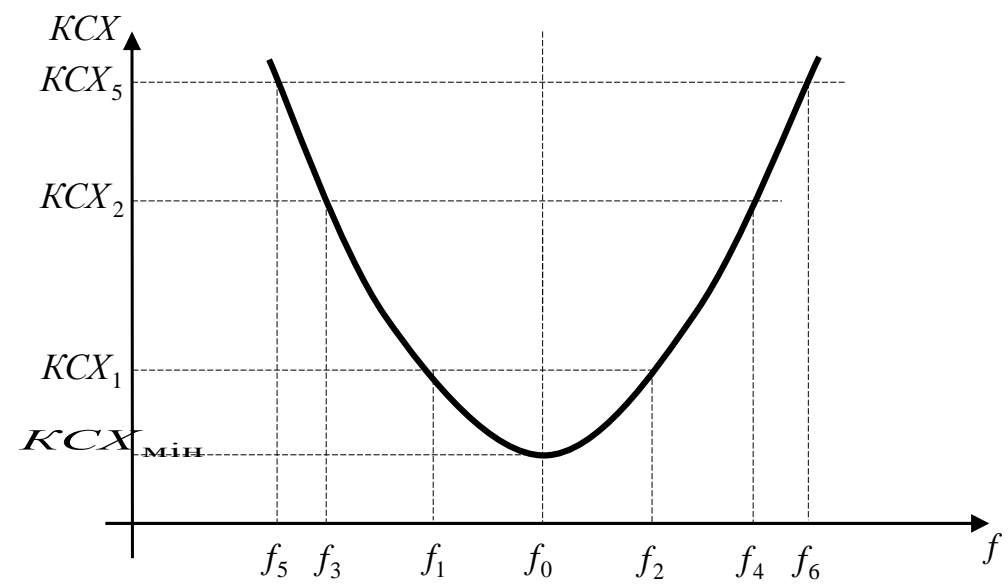

Рис. 8. Залежність КСХ резонатора від частоти

За значеннями КСХ, які відповідають точкам перетину 1, 2 і 3 цих допоміжних ліній $з$ кривою сталого значення $R / Z_{0}=K C X_{\text {мін }}$ (рис. 7), можна визначити частоти $f_{1}-f_{2}$, що відповідають $K C X_{1}$, і частоти $f_{3}-f_{4}, f_{5}-f_{6}$, які відповідають $K C X_{2}, K C X_{3}$, як показано на рисунку 8 , можна обчислити добротності резонатора, скористуючись формулами із робіт $[1,13]$ :

$$
Q_{0}=\frac{f_{0}}{f_{1}-f_{2}}, Q_{H}=\frac{f_{0}}{f_{3}-f_{4}}, Q_{3}=\frac{f_{0}}{f_{5}-f_{6}} .
$$

Отже, за експериментального способу графічної побудови на круговій діаграмі повних опорів можна визначити значення всіх основних параметрів резонатора.

Структурну схему установки для вимірювання параметрів НВЧ-резонаторів наведено на рисунку 5 .

НВЧ-потужність, що поступає на вхід плеча Е, визначається за виразом із $[8,13]$

$$
P=P_{0}\left(1-\left|\dot{\Gamma}_{3}\right|^{2}\right)\left|\frac{\dot{\Gamma}_{1}-\dot{\Gamma}_{2}}{2-\dot{\Gamma}_{3}\left(\dot{\Gamma}_{1}+\dot{\Gamma}_{2}\right)}\right|,
$$

де $P_{0}$ - потужність на вході хвилеводного моста; $\dot{\Gamma}_{3}-$ коефіцієнт відбиття від Е-плеча; $\dot{\Gamma}_{1}, \dot{\Gamma}_{2}-$ коефіцієнти відбиття від Н-плеча.

Для коефіцієнта відбиття однозв'язного резонатора з урахуванням затухання в елементі зв'язку [13]:

$$
\Gamma_{p}=k \frac{\beta-1}{\beta+1}-\frac{i Q_{H} \frac{2 \Delta f}{f_{0}}}{1+i Q_{H} \frac{2 \Delta f}{f_{0}}},
$$

де $\frac{\Delta f}{f_{0}}$ - відносне розстроєння резонатора; $k$ - коефіцієнт затухання за потужністю в елементі зв'язку.

Поза смугою пропускання резонатора, коли його коефіцієнт відбиття дорівнює мінус $k$, за допомогою короткозамикаючого поршня і атенюатора виконується балансування моста.

3 виразів (10) і (11) виходить, що за настроювання генератора, коли резонансна частота лежить у смузі зміни частоти, потужність на вході плеча Н-моста визначається так:

$$
P_{1}=k^{2} P_{0}\left|\frac{\frac{\beta}{\beta+1}}{1+i Q_{H} \frac{2 \Delta f}{f_{0}}}\right|^{2} .
$$

При переміщенні поршня на четверть довжини хвилі, тобто за максимального розбалансування моста, потужність на рівні провалу, коли $\Delta f=0$, дорівнює 


$$
P_{2}=k^{2} P_{0}\left(\frac{1}{\beta+1}\right)^{2} .
$$

3 виразів (12) і (13) виходить, що на резонансній частоті $f_{0}$ виконується співвідношення

$$
P_{1} / P_{2}=\beta^{2},
$$

яке використовують для визначення параметрів зв'язку.

Вимірювання виконують у такій послідовності:

- $\quad$ поза смугою пропускання за допомогою короткозамикача і атенюатора 7 балансується міст і за шкалою атенюатора визначається затухання в елементі зв'язку;

- потім перестроюється генератор до отримання на екрані панорамного вимірювача КСХН резонансної характеристики (рис. 9). За допомогою атенюатора 5 і частотної мітки визначається навантажена добротність, яка розрахована за формулою (9);

- короткозамикаючим поршнем розбалансовують міст до отримання максимального провалу на зоні генерації (рис. 10) і атенюатором 5 поєднується максимум із рівнем сигналу панорамного вимірювача КСХН. За різницею показів атенюатора коефіцієнт зв'язку визначається за формулою (14).

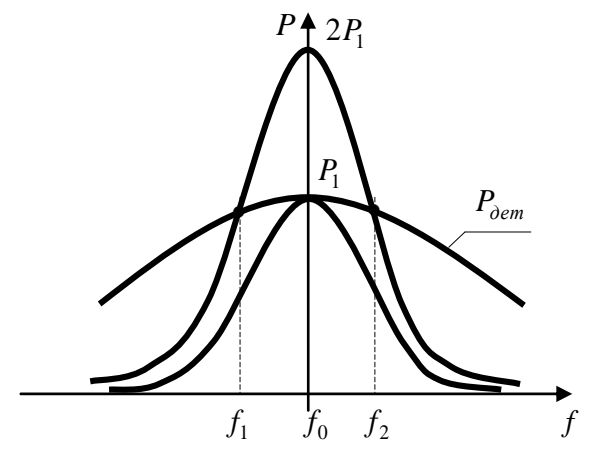

Рис. 9. Залежність НВЧ-потужності від частоти в незбалансованому подвійному хвилеводному трійнику

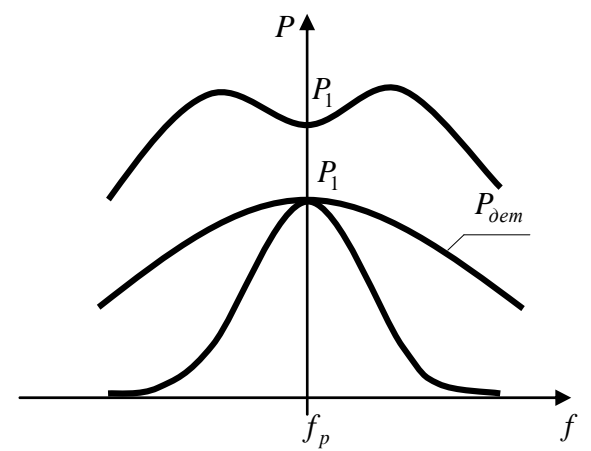

Рис. 10. Залежність НВЧ-потужності за незбалансованого подвійного хвилеводного трійника

Розглянемо основні положення. 3 виразу (12) можна визначити похибку вимірювання навантаженої добротності $Q_{H}$

$$
Q_{H}=\frac{f_{0}}{2 \Delta f}\left(\frac{P_{1}^{0}}{P_{1}^{1}}-\right)^{-1 / 2},
$$

де $P_{1}^{0}=2 P_{1}^{0}$ - потужність на вході мосту на резонансній частоті.

3 цієї формули для похибки вимірювання $Q_{\mu}$ отримуємо вираз

$$
\frac{\delta Q_{H}}{Q_{H}}=\frac{\delta f_{0}}{f_{0}}+\frac{\delta \Delta f}{\Delta f}+\frac{1}{2} \delta \frac{P_{1}^{0}}{P_{1}^{1}},
$$

де $\frac{\delta f_{0}}{f_{0}}$ - відносна похибка вимірювання резонансної частоти; $\frac{\delta \Delta f}{\Delta f}-$ відносна похибка вимірювання смуги пропускання резонатора. 
Оскільки

$$
A=10 \lg \frac{P_{1}^{0}}{P_{1}^{1}},
$$

де $A-$ різниця показів атенюатора (у дБ), з (17), маємо

$$
\delta \frac{P_{1}^{0}}{P_{1}^{1}}=\frac{\delta}{5 \lg c},
$$

де $\delta A$ - похибка вимірювання затухання (у дБ), дорівнює половині поділки шкали атенюатора. Таким чином, для похибки вимірювання добротності отримуємо вираз

$$
\frac{\delta Q_{H}}{Q_{H}}=\frac{\delta f_{0}}{f_{0}}+\frac{\delta \Delta f}{\Delta f}+0,23 \delta A+\left|k \dot{\Gamma}_{3}\right|,
$$

де $\left|k \Gamma_{3}\right|-$ член, який враховує відбиття в плечі 3 моста та затухання в елементі зв’язку.

Аналогічно для похибки вимірювання коефіцієнта зв'язку отримуємо формулу

$$
\frac{\delta \beta}{\beta}=0,115 \delta A+\left|k \dot{\Gamma}_{3}\right| .
$$

Для коефіцієнта відбиття в Е-плечі моста можна записати такий вираз

$$
\dot{\Gamma}_{E}=\Gamma_{E} e^{i \varphi}
$$

де $\dot{\Gamma}_{E}-$ комплексний коефіцієнт відбиття в плечі Е;

$\varphi$ - фаза, пов'язана із набіганням фази хвилі у Е-плечі моста, що визначається таким чином.

За підключення замість досліджуваного резонатора короткозамикаючого поршня і атенюатора, які $\epsilon$ еталонним навантаженням, визначається величина $\dot{\Gamma}_{E}$. Після цього до Е-плеча моста підключається короткозамикач i, за допомогою поршня, балансується та визначається нульова фаза.

Тоді формули (20) та (21) можна записати так:

$$
\begin{aligned}
& \frac{\delta Q_{H}}{Q_{H}}=\frac{\delta f_{0}}{f_{0}}+\frac{\delta \Delta f}{\Delta f}+0,23 \delta A+|k \dot{\Gamma}|^{2}+2 \delta\left|k \dot{\Gamma}_{3}\right|, \\
& \frac{\delta \beta}{\beta}=0,115 \delta A+\left|k \dot{\Gamma}_{1}\right|^{2}+2 \delta\left|\dot{\Gamma}_{3}\right|,
\end{aligned}
$$

де $\delta|\dot{\Gamma}|$ - абсолютна похибка вимірювання коефіцієнта відбиття в Е-плечі моста.

Похибку вимірювання, пов'язану із несиметрією моста, оцінюють так.

Вираз для потужності на вході моста згідно із (10) та(12) за $\Delta f=0$ можна записати як

$$
\begin{aligned}
& P_{1}=k^{2} P_{0}\left(\frac{\beta}{\beta+1}\right)^{2}+\delta P, \\
& P_{2}=k^{2} P_{0}\left(\frac{1}{\beta+1}\right)^{2}+\delta P,
\end{aligned}
$$

де $\delta P$ - потужність, обумовлена несиметричністю моста.

Тоді

$$
\frac{P_{1}}{P_{2}} \approx \beta^{2}\left[1+\frac{\delta P}{k^{2} P_{0}}\left(\frac{1-\beta^{2}}{\beta}\right)^{2}\right]
$$

і як видно із цього виразу, несиметричність Т-мосту переважно залежить від коефіцієнта зв'язку $\beta$ та відношення потужностей.

Висновки та перспективи подальших досліджень. Проведені теоретичні та експериментальні дослідження методу вимірювання добротності НВЧ-резонаторів за допомогою моста показують можливість застосування його в різних радіотехнічних системах НВЧ-діапазону.

Експериментальні дослідження об’ємних квадратних і круглих хвилевідних резонаторів показали, що реальний несиметричний Т-міст балансується без використання додаткових підстроювальних елементів на рівні більше 40 дБ, тому його несиметрія вносить у похибку вимірювання вклад менше $1 \%$ для значень $\beta$, що знаходяться в межах $10^{-1} \ldots 10$.

Виміряні добротності $Q_{0}$ досягають значень $10^{4}$, за цього похибка вимірювань $Q_{\mu}$ визначається в основному похибкою вимірювання смуги пропускання і становить в середньому $3 . .5 \%$. 
Метод не накладає суттєвих обмежень на верхню границю вимірюваних добротностей $Q_{H}$ та визначається смугою частот, в яких можливо збалансувати подвійний хвилевідний трійник.

\section{Список використаної літератури:}

1. Бова М.Т. Вимірювання параметрів антен і пристроїв НВЧ / М.Т. Бова, І.Б. Лайхтман. - К. : Вища школа, 1973. - $109 \mathrm{c}$.

2. Тишер $\Phi$. Техника измерений на сверхвысоких частотах / Ф.Тишер. - М. : Госиздат физико-математической литературы, 1963. - 367 с.

3. Зайщев А.Н. Измерения на сверхвысоких частотах и их метрологическое обеспечение / А.Н. Зайщев, П.А. Иващенко, А В. Мыльнников. - М. : Изд. стандартов, 1989. - 237 с.

4. Чернушенко A.M. Измерения параметров электронных приборов дециметрового и сантиметрового диапазонов волн / А.М. Чернушенко, А.В. Майбородин. - М. : Радио и связь, 1986. -336 с.

5. Абубакиров Б.Ф. Измерения параметров радиотехнических цепей / Б.Ф. Абубакиров, К.Г. Гурков, Э.В. Нечаев. - М. : Радио и связь, 1984. -247 с.

6. Кушнир Ф.В. Измерения в технике связи / Ф.В. Кушнир, В.Г. Савенко, С.М. Верник. - М. : Связь, 1978. - 430 с.

7. Кушнир Ф.В. Электрорадиоизмерения / Ф.В. Кушнир, В.Г. Савенко. - Л. : Энергия, 1975. - 367 с.

8. Усовершенствованный мостовой метод измерения параметров СВЧ-резонаторов с одним элементом связи / В.М. Буторин, В.Е. Горлачев, И.А. Гудзь, Л.Ф. Хоменко // Электронная техника. Электроника СВЧ. - 1977. № 1. - С. 70-75.

9. Метод вимірювання ефективної діелектричної проникності частково заповнених хвилеводів за допомогою неузгодженого Т-мосту / Н.М. Карашук, В.П. Манойлов, О.Л. Сидорчук та ін. // Вісник НТТУ «Київський політехнічний інститут». - 2019. - Вип. 78. - С. 6-13.

10. Брянский Л.Н. Радиоизмерения. Методы и средства, погрешности / Л.Н. Брянский, М.М. Левин, В.Я. Розенберг. - М. : Изд. стандартов, 1970. - 336 с.

11. Манойлов В.П. Методи розрахунку та вимірювання параметрів і характеристик антен / В.П. Манойлов, П.П. Мартинчук. - Житомир : Рута, 2021. - 202 с.

12. Гольдштейн Л.Д. Электромагнитные поля и волны / Л.Д. Гольдштейн, Н.В. Зернов. - М. : Сов. радио. 1971. $-662 \mathrm{c}$.

13. Альтман Д.П. Устройства сверхвысоких частот / Д.П. Альтман. - М. : Мир, 1968. - 250 с.

\section{References:}

1. Bova, M.T. and Lajhtman, I.B. (1973), Vymirjuvannja parametriv anten i prystroi'v NVCh, Vyshha shkola, K., 109 p.

2. Tisher, F. (1963), Tekhnika izmerenii na sverkhvysokikh chastotakh, Gosizdat fiziko-matematicheskoi literatury, M., 367 p.

3. Zaitsev, A.N., Ivashchenko, P.A. and Myl'nikov, A.V. (1989), Izmereniya na sverkhvysokikh chastotakh i ikh metrologicheskoe obespechenie, Izd. standartov, M., 237 p.

4. Chernushenko, A.M. and Maiborodin, A.V. (1986), Izmereniya parametrov elektronnykh priborov detsimetrovogo $i$ santimetrovogo diapazonov voln, Radio i svyaz', M., 336 p.

5. Abubakirov, B.F., Gurkov, K.G. and Nechaev, E.V. (1984), Izmereniya parametrov radiotekhnicheskikh tsepei, Radio i svyaz', M., 247 p.

6. Kushnir, F.V., Savenko, V.G. and Vernik, S.M. (1978), Izmereniya v tekhnike svyazi, Svyaz', M., 430 p.

7. Kushnir, F.V. and Savenko, V.G. (1975), Elektroradioizmereniya, Energiya, L., 367 p.

8. Butorin, V.M., Gorlachev, V.E., Gudz', I.A. and Khomenko, L.F. (1977), «Usovershenstvovannyi mostovoi metod izmereniya parametrov SVCh-rezonatorov s odnim elementom svyazi», Elektronnaya tekhnika. Elektronika SVCh, No. 1, pp. 70-75.

9. Karashhuk, N.M., Manojlov, V.P., Sydorchuk, O.L. ta in. (2019), «Metod vymirjuvannja efektyvnoi' dielektrychnoi' pronyknosti chastkovo zapovnenyh hvylevodiv za dopomogoju neuzgodzhenogo T-mostu», Visnyk NTTU «Kyi'vs'kyj politehnichnyj instytut», Issue 78, pp. 6-13.

10. Bryanskii, L.N., Levin, M.M. and Rozenberg, V.Ya. (1970), Radioizmereniya. Metody i sredstva, pogreshnosti, Izd. standartov, M., $336 \mathrm{p}$.

11. Manojlov, V.P. and Martynchuk, P.P. (2021), Metody rozrahunku ta vymirjuvannja parametriv i harakterystyk anten, Ruta, Zhytomyr, $202 \mathrm{p}$.

12. Gol'dshtein, L.D. and Zernov, N.V. (1971), Elektromagnitnye polya i volny, Sov. radio, M., 662 p.

13. Al'tman, D.P. (1968), Ustroistva sverkhvysokikh chastot, Mir, M., 250 p.

Каращук Наталія Миколаївна - кандидат технічних наук, доцент, старший викладач Житомирського військового інституту ім. С.П. Корольова.

http://orcid.org/0000-0002-5691-2098.

Наукові інтереси:

- антени та техніка НВЧ.

E-mail: knm7@ukr.net. 
Манойлов В'ячеслав Пилипович - доктор технічних наук, професор, професор кафедри біомедичної інженерії і телекомунікацій Державного університету «Житомирська політехніка».

http://orcid.org/0000-0001-6961-6995.

Наукові інтереси:

- електродинаміка;

- прилади НВЧ та антени;

- біомедичні прилади та системи.

E-mail: kaf.rrat@ukr.net.

Мартинчук Петро Петрович - старший викладач кафедри біомедичної інженерії та телекомунікацій Державного університету «Житомирська політехніка».

http://orcid.org/ 0000-0002-3220-6033.

Наукові інтереси:

- обробка сигналів у радіотехнічних системах;

- антени;

- електро- та радіовимірювальні прилади.

E-mail:m_petro@ukr.net.

Чухов Владислав Вікторович - кандидат технічних наук, доцент, доцент кафедри біомедичної інженерії та телекомунікацій Державного університету «Житомирська політехніка».

https://orcid.org/0000-0001-7782-9077.

Наукові інтереси:

- радіовимірювання;

- пристрої НВЧ;

- антени.

E-mail: mps_cvv@ukr.net. 